\title{
The Effect of Dispersion-Medium Composition and Ionomer Concentration on the Microstructure and Rheology of Fe-N-C Platinum Group Metal-Free Catalyst Inks for Polymer Electrolyte Membrane Fuel Cells
}

Sunilkumar Khandavalli ${ }^{1}$, Radhika Iyer ${ }^{1}$, Jae Hyung Park' ${ }^{2}$, Deborah J. Myers ${ }^{2}$, K. C. Neyerlin ${ }^{1}$, Michael Ulsh', and Scott A. Mauger ${ }^{*}$

${ }^{1}$ Chemistry and Nanoscience Center, National Renewable Energy Laboratory, Golden, CO

$$
\text { 80401, USA }
$$

${ }^{2}$ Chemical Sciences and Engineering Division, Argonne National Laboratory, Lemont, IL

$$
\text { 60439, USA }
$$

E-mail: scott.mauger@nrel.gov

Phone: +1 (303) 3847371

\section{Supplementary Information}

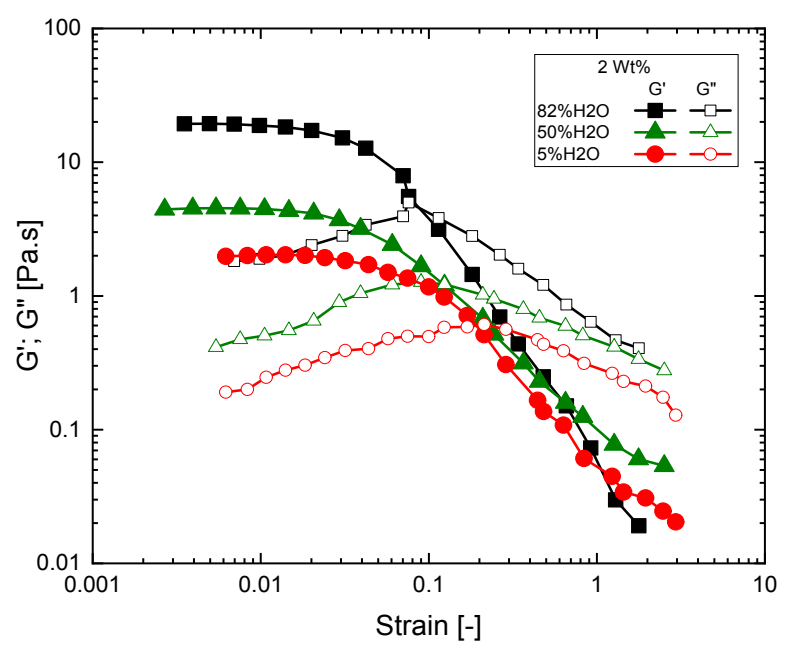

Figure S1. Amplitude-sweep measurements: elastic ( $\left.G^{\prime}\right)$ and loss $\left(G^{\prime \prime}\right)$ moduli as a function of strain amplitude, for inks at different $\mathrm{H}_{2} \mathrm{O} \%$ in dispersion media. 